\title{
Heavy metals in soil and accumulation in medicinal plants at an industrial area in Enyimba city, Abia State, Nigeria
}

\author{
Ogbonna, P.C. ${ }^{1{ }^{\prime} *}$, Nzegbule, E.C. ${ }^{1}$, Obasi, K.O. ${ }^{1}$ and Kanu, H. ${ }^{1}$ \\ ${ }^{1}$ Department of Environmental Management and Toxicology, Michael Okpara University of Agriculture, \\ Umudike, PMB 7267 Umuahia, Abia State, Nigeria \\ Corresponding Author: *ogbonna_princewill@yahoo.com
}

\begin{abstract}
The study assessed heavy metals in the soil and subsequent accumulation in plants at an industrial site at Enyimba city, Abia State, Nigeria. Soil and medicinal plant samples were analyzed for zinc $(\mathrm{Zn})$, lead $(\mathrm{Pb})$ and cadmium $(\mathrm{Cd})$. The highest concentration of $\mathrm{Zn}(142.06 \pm 2.91 \mathrm{mg} / \mathrm{kg}), \mathrm{Pb}$ $(18.06 \pm 1.30 \mathrm{mg} / \mathrm{kg})$ and $\mathrm{Cd}(27.055 \pm 2.468 \mathrm{mg} / \mathrm{kg})$ were obtained at the sampling points of 2,7 and 5, respectively. The highest concentrations of $\mathrm{Zn}(27.09 \pm 1.44 \mathrm{mg} / \mathrm{kg})$ and $\mathrm{Cd}(2.000 \pm 0.156$ $\mathrm{mg} / \mathrm{kg})$ were accumulated by Azadiractha indica while the highest concentration of $\mathrm{Pb}(4.58 \pm 0.51$ $\mathrm{mg} / \mathrm{kg}$ ) was accumulated by Mangifera indica. The levels of $\mathrm{Zn}$ and $\mathrm{Cd}$ in soil were $13.77 \pm 1.35$ to $142.06 \pm 2.91$ and $0.695 \pm 0.106$ to $27.055 \pm 2.468$, and their concentrations in Azadiractha indica were $5.06 \pm 0.35$ to $27.09 \pm 1.44$ and $0.002 \pm 0.001$ to $2.000 \pm 0.156 \mathrm{mg} / \mathrm{kg}$, respectively. The concentrations of $\mathrm{Zn}$ and $\mathrm{Cd}$ in soil and $\mathrm{Cd}$ in Azadiractha indica reflected a state of pollution relative to Dutch criteria for soil and the FAO/WHO Codex Alimentarius Commission for soil and herbal plants.
\end{abstract}

Keywords: Medicinal plants, heavy metals, industrial area, Enyimba city, Nigeria

\subsection{Introduction}

The use of medicinal plants for therapeutic purpose or as a dietary supplement dates back beyond records of history, but have increased substantially in the last decade (WHO, 2002). Medicinal plants are applied as single plants, which action is directed at individual ailments, as plant mixtures, syrups, plants and fruit-plant teas and as spices (Ozarowski and Jaroniewski, 1987). Thus, a large populace of people in developing countries relied heavily on medicinal plants for their primary health care because of the low price and safety of active ingredients in plant materials.

The atmosphere is an important pathway for transport of metals and the major external input of bioavailable metals in the environment, which are potential threats to the health and survival of man. This is because urban atmosphere is submitted to large inputs of metals arising from stationary source such as industries. The metals are either deposited directly on plant surfaces such as leaves, flowers, branches, and stems or on soils, which are absorbed from the soil solution into plants via the roots. Therapeutic use of medicinal plants contaminated with heavy metals may lead to hazards of enriching human alimentary canal with toxic levels of metals. For instance, the prevalence of upper gastrointestinal cancer in the Van region of Turkey has been linked to metal pollution in soil, fruits and vegetables (Turkdogan et al., 2003).

Among the medicinal plants commonly seen in home gardens at Enyimba city are Azadiractha indica, Citrus sinensis, Psidium guajava, Mangifera indica, Vernonia amygdalina, Occimum gratissimum, and Carica papaya. These plants extracts has undergone extensive pharmacological screening and found to have several pharmacological activities due to presence of several active ingredients. Notwithstanding this, there is increasing concern in environmental connection with human health. Consequently, there is need to investigate the level of concentrations of metals in medicinal plants around the industrial area in Enyimba city. This will enhance the knowledge of the people on the possible health hazards of using medicinal plants contaminated with heavy metals. 


\subsection{Materials and Methods}

\subsection{Study area}

The study was carried out at Enyimba city. The Enyimba city is the major industrial and commercial hub of Abia State and it is located in the lowland rainforest zone of Nigeria (Keay, 1959). It lies on latitude $5^{\circ} 1^{\prime} \mathrm{N}$ and longitude $7^{\circ} 35^{\prime} \mathrm{E}$ and characterized by heavy rainfall and short dry season. The mean annual rainfall is 150 to $186 \mathrm{~mm}$, and annual relative humidity is over $80 \%$ while the mean annual temperature exceeds $21^{\circ} \mathrm{C}$.

\subsection{Sampling collection and analysis}

A simple factorial experiment in a randomized complete block design was used to carry out the study. Twenty three (3) surface soil samples $(0-15 \mathrm{~cm})$ each were collected randomly from seven (7) different sampling positions $(1,2,3,4,5,6$, and 7) at industrial and residential areas and stored in cellophane bags, labelled well, and taken to the laboratory for pre-treatment and analysis. The residential area where there was no industry served as control. Twenty three samples from each sampling positions were bulked separately (e.g. 23 samples of $0-15 \mathrm{~cm}$ at sampling position 1), homogenized and air dried in circulating air in an oven at $30^{\circ} \mathrm{C}$ to constant weight and passed through a $2 \mathrm{~mm}$ sieve. The procedure described by MAFF (1981) was used for the digestion of soil samples. Exactly $1 \mathrm{~g}$ of sub samples were placed in a $100 \mathrm{ml}$ beaker and $10 \mathrm{ml} \mathrm{HNO} 3$ acid and $3 \mathrm{ml} \mathrm{HClO} 4$ were added and the solution was heated until fuming. Sample solution was obtained by processing with $4 \mathrm{ml}$ hot $\mathrm{E} \mathrm{mol} / \mathrm{Hec}$, filtered and diluted with water in a $50 \mathrm{ml}$ standard flask. Triplicate digestion of each sample together with a blank was also carried out and metallic content of digested samples were determined with flame atomic absorption spectrophotometer (UNICAM 919 Model) after calibration.

Fresh leaves were sampled from twenty one (21) stands each of Azadiractha indica, Citrus sinensis, Psidium guajava, Mangifera indica, Vernonia amygdalina, Occimum gratissimum, and Carica papaya from where soil samples were collected at industrial and residential areas. The fresh leaves were collected randomly from the various branches of the medicinal plants (except for Carica papaya that does not have branches). The samples from each plant species were placed in large paper bags, labelled well and transferred to the Laboratory for pre-treatment and analysis. The plant samples were thoroughly rinsed with distilled-deionized water to remove dust and pollen particles and placed in large crucibles and oven dried at $70^{\circ} \mathrm{C}$ for $72 \mathrm{hrs}$. The dried samples from each species were bulked together and milled with a Thomas Wiley machine. Sub samples were collected from the milled samples and analysed for heavy metals. The procedure described by Allen et al. (1976) was used for sample digestion. Exactly $0.2 \mathrm{~g}$ of each samples were weighed into $100 \mathrm{ml}$ standard flask and $1 \mathrm{ml}$ per chloric acid and $5 \mathrm{ml}$ conc. $\mathrm{HNO}_{3}$ added and digested at $80-90^{\circ} \mathrm{C}$ on hot plates until white fumes evolved. The digest was allowed to cool and then filtered into $50 \mathrm{ml}$ standard flask with watchman No 1 filter paper. Triplicate digestion of each sample together with a blank was also carried out and metallic content of digested samples was determined with flame atomic absorption spectrophotometer (UNICAM 919 Model) after calibration. Data from the result of laboratory analysis were subjected to analysis of variance (ANOVA) and means were separated with Duncan Multiple Range Test.

\subsection{Experimental design and statistical analysis}

A Single Factor Experiment in a randomized complete block design (RCBD) was used to carry out the experiment. The data generated from laboratory analysis were subjected to analysis of variance (ANOVA) using Statistical Package for Social Sciences (SPSS) version 15.0. Analysis of variance was performed using a One-way ANOVA and Duncan Multiple Range Test (DMRT) was used to test if significance difference existed between mean concentrations in physical parameters and heavy metals in water, fish and sediment from the different sampling stations. 


\subsection{Results and Discussion}

\subsection{Heavy metal in soil}

The result of the concentrations of heavy metals in soil is summarized in Table 1 . The result indicates that the highest and lowest concentrations of metals in soils were observed at the industrial area and the residential area, respectively. The lower concentration of metals at the residential area (i.e. control) is attributed to the absence of industry (ies) in that location. The highest concentrations of $\mathrm{Zn}$ $(142.06 \pm 2.91 \mathrm{mg} / \mathrm{kg}), \mathrm{Pb}(18.06 \pm 1.30 \mathrm{mg} / \mathrm{kg})$, and $\mathrm{Cd}(27.055 \pm 2.468 \mathrm{mg} / \mathrm{kg})$ were obtained at the sampling points of 2,5 and 7 , respectively at the industrial area and these values are significantly $(\mathrm{P}<$ $0.05)$ higher than their highest corresponding values $(35.59 \pm 0.69,8.99 \pm 1.03$, and $1.060 \pm 0.042$ $\mathrm{mg} / \mathrm{kg}$ ) at the residential area, respectively. The high values of $\mathrm{Zn}, \mathrm{Pb}$, and $\mathrm{Cd}$ at the industrial area are attributed to various industrial activities taken place in the location. Mobilization of metals into the atmosphere as a result of anthropogenic activities is an important process in the geochemical cycling of heavy metals. This is acutely evident in urban areas where various stationary and mobile sources release large quantities of metals into the atmosphere and soil (Bilos et al., 2001).

The highest concentration of $\mathrm{Zn}, \mathrm{Pb}$ and $\mathrm{Cd}$ at the industrial area is 3.99, 2.01 and 25.52 times higher than their highest concentrations at residential area, respectively. According to Logan and Miller (1983), soil is said to be contaminated when concentrations of an element in soils were two-to-three times higher than the control. The soils at the industrial area is considered to be contaminated base on the findings that $\mathrm{Cd}, \mathrm{Zn}$ and $\mathrm{Pb}$ concentrations in the control soil samples are significantly lower compared to their corresponding values at the industrial area. The concentrations of $\mathrm{Zn}$ and $\mathrm{Cd}$ in soils of the industrial area of Enyimba city, Nigeria were $13.77 \pm 1.35$ to $142.06 \pm 2.91$ and $0.695 \pm 0.106$ to $27.055 \pm 2.468$, respectively for $\mathrm{Zn}$ and $\mathrm{Cd}$ which are above the accepted limits (i.e. target value) of $140 \mathrm{mg} / \mathrm{kg}(\mathrm{Zn})$ and $0.8 \mathrm{mg} / \mathrm{kg}(\mathrm{Cd})$ as described by Dutch criteria for soil (Wikipedia, 2013) and the maximum permitted levels of $60 \mathrm{mg} / \mathrm{kg}(\mathrm{Zn})$ and $0.1 \mathrm{mg} / \mathrm{kg}(\mathrm{Cd})$ established by the Codex Alimentarius Commission (FAO/WHO, 2001) (Table 2). The concentration of $\mathrm{Pb}(4.91 \pm 1.26$ to $18.06 \pm 1.30 \mathrm{mg} / \mathrm{kg}$ ) in soils at the industrial area is below the accepted limits (i.e. target value) of 85 $\mathrm{mg} / \mathrm{kg}(\mathrm{Pb})$ as described by Dutch criteria for soil (Wikipedia, 2013) and the maximum permitted levels of $50 \mathrm{mg} / \mathrm{kg}(\mathrm{Pb})$ established by the Codex Alimentarius Commission (FAO/WHO, 2001) Table 2). The values of $\mathrm{Zn}$ range from $9.22 \pm 1.14 \mathrm{mg} / \mathrm{kg}$ at the residential area to $142.06 \pm 2.91$ $\mathrm{mg} / \mathrm{kg}$ at the industrial area, which is relatively lower than 114.0 to $162.0 \mathrm{mg} / \mathrm{kg}$ for $\mathrm{Zn}$ in soils at industrial sites in Isfahan, Iran (Fallahzade et al., 2013) but higher than $59.85 \pm 0.002$ to $64.5 \pm 0.014$ $\mathrm{mg} / \mathrm{kg}$ for $\mathrm{Zn}$ in soil at Kaduna, Nigeria (Ogundele et al., 2015), 0.01 to $1.26 \mathrm{ppm}$ for $\mathrm{Zn}$ in soils around Superphosphate factory at Assiut city, Egypt (El-Desoky and Ghallab, 2000) but well below 93.0 to $2841 \mathrm{mg} / \mathrm{kg}$ for $\mathrm{Zn}$ in soils around a smelter at Slovenia (Glavac et al., 2017). The values of $\mathrm{Pb}$ in this study range from $1.02 \pm 0.04 \mathrm{mg} / \mathrm{kg}$ at the residential area to $18.06 \pm 1.30 \mathrm{mg} / \mathrm{kg}$ at the industrial area, which is higher than 0.102 to $1.082 \mathrm{ppm}$ for Pb (El-Desoky and Ghallab, 2000) but substantially lower than 45.0 to $4132 \mathrm{mg} / \mathrm{kg}$ for $\mathrm{Pb}$ (Glavac et al., 2017) and $27.0 \pm 0.005$ to $238.0 \pm$ $0.003 \mathrm{mg} / \mathrm{kg}$ for $\mathrm{Pb}$ in soil (Ogundele et al., 2015) while the values of Cd range from $0.275 \pm 0.332$ at the residential area to $27.055 \pm 2.468 \mathrm{mg} / \mathrm{kg}$ at the industrial area, which is higher than $0.033 \pm 0.003$ to $0.100 \pm 0.002 \mathrm{mg} / \mathrm{kg}$ for Cd in soil (Ogundele et al., 2015) and 0.002 to $0.140 \mathrm{ppm}$ for Cd (ElDesoky and Ghallab, 2000) but well below 0.40 to $74.7 \mathrm{mg} / \mathrm{kg}$ for Cd (Glavac et al., 2017). Generally, the concentrations of heavy metals in soil followed a decreasing order: $\mathrm{Zn}>\mathrm{Cd}>\mathrm{Pb}$. 
Table 1: Heavy metal concentration $(\mathrm{mg} / \mathrm{kg})$ in soil

\begin{tabular}{|l|l|l|l|}
\hline & $\mathrm{Zn}$ & $\mathrm{Pb}$ & $\mathrm{Cd}$ \\
\hline & $58.66^{\mathrm{c}} \pm 3.34$ & $10.7^{\mathrm{de}} \pm 0.05$ & $1.160^{\mathrm{d}} \pm 0.113$ \\
\hline & $142.06^{\mathrm{a}} \pm 2.91$ & $16.35^{\mathrm{ab}} \pm 1.20$ & $9.210^{\mathrm{c}} \pm 1.683$ \\
\hline & $58.66^{\mathrm{c}} \pm 2.20$ & $4.91^{\mathrm{g}} \pm 1.26$ & $1.490^{\mathrm{d}} \pm 0.156$ \\
\hline & $26.57^{\mathrm{e}} \pm 2.17$ & $11.08^{\mathrm{d}} \pm 0.37$ & $1.170^{\mathrm{d}} \pm 0.042$ \\
\hline & $105.30^{\mathrm{b}} \pm 4.38$ & $16.41^{\mathrm{a}} \pm 1.68$ & $27.055^{\mathrm{a}} \pm 2.468$ \\
\hline & $13.77^{\mathrm{g}} \pm 1.35$ & $12.97^{\mathrm{c}} \pm 1.18$ & $0.695^{\mathrm{e}} \pm 0.106$ \\
\hline & $57.08^{\mathrm{c}} \pm 0.45$ & $18.06^{\mathrm{a}} \pm 1.30$ & $14.005^{\mathrm{b}} \pm 0.290$ \\
\hline & $18.55^{\mathrm{ef}} \pm 2.19$ & $3.07^{\mathrm{gh}} \pm 0.22$ & $0.550^{\mathrm{ef}} \pm 0.651$ \\
\hline & $27.41^{\mathrm{e}} \pm 1.83$ & $1.64^{\mathrm{i}} \pm 0.31$ & $1.005^{\mathrm{d}} \pm 0.007$ \\
\hline & $11.76^{\mathrm{g}} \pm 1.07$ & $1.02^{\mathrm{ij}} \pm 0.04$ & $0.275^{\mathrm{f}} \pm 0.332$ \\
\hline & $9.86^{\mathrm{h}} \pm 1.20$ & $5.68^{\mathrm{f}} \pm 0.48$ & $1.060^{\mathrm{d}} \pm 0.042$ \\
\hline & $21.56^{\mathrm{ef}} \pm 2.21$ & $8.99^{\mathrm{e}} \pm 1.03$ & $0.790^{\mathrm{e}} \pm 0.099$ \\
\hline & $9.22^{\mathrm{h}} \pm 1.14$ & $3.59^{\mathrm{gh}} \pm 0.53$ & $0.305^{\mathrm{f}} \pm 0.035$ \\
\hline & $35.59^{\mathrm{d}} \pm 0.69$ & $5.20^{\mathrm{fg}} \pm 0.57$ & $0.520^{\mathrm{ef}} \pm 0.085$ \\
\hline
\end{tabular}

$a, b, c, d, e, f, g, h, i, j$, means in a column with different superscript are significantly different $(P<0.05)$. Values are mean \pm standard deviation of 3 replications

Table 2: Comparison of our result with International Standard (Dutch criteria and FAO/WHO Codex Alimentarius Commission

\begin{tabular}{|l|l|l|l|}
\hline & $\begin{array}{l}\text { Dutch criteria } \\
\text { (target value) } \mathrm{mg} / \mathrm{kg}\end{array}$ & $\begin{array}{l}\text { FAO/WHO 2001 } \\
\text { Codex Alimentarius Commission }(\mathrm{mg} / \mathrm{kg})\end{array}$ & $\begin{array}{l}\text { NESREA 2011 } \\
\text { Standard }(\mathrm{mg} / \mathrm{kg})\end{array}$ \\
\hline $\mathrm{Zn}$ & 140 & 60 & 421 \\
\hline $\mathrm{Pb}$ & 85 & 50 & 164 \\
\hline $\mathrm{Cd}$ & 0.8 & 0.1 & 3 \\
\hline
\end{tabular}

\subsection{Heavy metal accumulation in plants}

The result of heavy metal accumulation in medicinal plants is summarized in Table 3 . The result shows that samples of medicinal plants collected from the environment of the industrial area were more contaminated with the metals $(\mathrm{Cd}, \mathrm{Pb}$ and $\mathrm{Zn})$. Some pollution studies in different sites in the world, such as Rome, Naples and Sydney, showed that air, soil or plants adjoined to source of pollutants had higher content of metals than a control area (Imperatoa et al., 2003; Moreno et al., 2003; Birch and Snowdon, 2004; Davila et al., 2006). The result also indicate that the concentrations of metals in the medicinal plants varied with plant species and metal contaminants with $\mathrm{Zn}$ being the most and $\mathrm{Cd}$ the least accumulated.

The highest concentration of $\mathrm{Zn}$ was obtained in Azadiractha indica $(27.09 \pm 1.44 \mathrm{mg} / \mathrm{kg})$ and the value is significantly $(\mathrm{P}<0.05)$ higher than its corresponding values in Psidium guajava $(19.77 \pm 1.17$ $\mathrm{mg} / \mathrm{kg})$, Mangifera indica $(15.45 \pm 0.92 \mathrm{mg} / \mathrm{kg})$, Vernonia amygdalina $(11.43 \pm 0.87 \mathrm{mg} / \mathrm{kg})$, Carica papaya $(9.36 \pm 0.95 \mathrm{mg} / \mathrm{kg})$, Citrus sinensis $(7.97 \pm 1.33 \mathrm{mg} / \mathrm{kg})$ and Ocimum gratissimum $(5.06 \pm$ $0.35 \mathrm{mg} / \mathrm{kg}$ ) at the industrial area as well as the values recorded for plants at the residential area (Table 3). The highest concentration of $\mathrm{Cd}$ was also obtained in Azadiractha indica (2.000 \pm 0.156 $\mathrm{mg} / \mathrm{kg})$ and the value is significantly $(\mathrm{P}<0.05)$ higher than values observed in Psidium guajava $(1.72$ $\pm 0.17 \mathrm{mg} / \mathrm{kg})$, Mangifera indica $(1.190 \pm 0.099 \mathrm{mg} / \mathrm{kg})$, Vernonia amygdalina $(0.055 \pm 0.021$ $\mathrm{mg} / \mathrm{kg})$, Carica papaya $(0.008 \pm 0.001 \mathrm{mg} / \mathrm{kg})$, Ocimum gratissimum $(0.005 \pm 0.002 \mathrm{mg} / \mathrm{kg})$ and Citrus sinensis $(0.002 \pm 0.001 \mathrm{mg} / \mathrm{kg})$ at the industrial area as well as the values recorded for plants at the residential area. The high concentration of $\mathrm{Zn}$ and $\mathrm{Cd}$ in $A$. indica may be attributed to inherent ability of the plant (A. indica) to absorb and translocate more $\mathrm{Zn}$ and $\mathrm{Cd}$ to the aerial plant parts (leaves) than other plants. Some plants can tolerate high heavy metals concentration from soil (McGrath et al., 2001) by binding metals to cell walls, compartmentalizing them in vacuoles or complexing them to certain organic acids or proteins (Reeves and Baker, 2000). The concentration of $\mathrm{Zn}$ increased from $1.15 \pm 0.09 \mathrm{mg} / \mathrm{kg}$ (Ocimum gratissimum) at the residential area to $27.09 \pm 1.44$ $\mathrm{mg} / \mathrm{kg}$ at the industrial area (Azadiractha indica). The level of $\mathrm{Zn}$ in this study is higher than $2.42 \pm$ 0.2173 to $8.93 \pm 0.0264 \mathrm{ppm}$ for $\mathrm{Zn}$ in Acacia nilotica, Bacopa monnieri, Commiphora wightii, Ficus religiosa, Glycyrrhiza glabra, Hemidesmus indicus, Salvadora oleoides, Terminalia bellirica, Terminalia chebula and Withania somnifera from north western India (Kulhari et al., 2013) but well below 23.2 to $799.5 \mathrm{mg} / \mathrm{kg}$ for $\mathrm{Zn}$ in Urtica dioica, Hypericum perforatum, Achillea millefolium, and Plantago lanceolata around a smelter at eight Meza Valley locations, Slovenia (Glavac et al., 2017), 12.65 to $146.67 \mathrm{mg} / \mathrm{kg}$ for $\mathrm{Zn}$ in Petroselinum crispum, Ocimum basilicum, Salvia officinalis, 
Origanum vulgare, Mentha spicata, Thymus vulgaris, and Matricaria chamomilla in the United Arab Emirates, UAE (Dghaim et al., 2015), and 83.74 to 433.76 for $\mathrm{Zn} \mu \mathrm{g} / \mathrm{g}$ in G. glabra, O. bracteatum, V. odorata, F. vulgare, C. cyminum, C. sativum, and Z. officinalis from Karachi city, Pakistan (Hina et al., 2011). The level of $\mathrm{Zn}$ in our study is below the permissible limit (PL) $50 \mathrm{mg} / \mathrm{kg}$ set by Codex Alimentarius Commission, FAO/WHO (2006) for medicinal plants and herbs but if the concentration of the metal in the plants at the industrial area continue to increase, it could pose significant health hazard to the population who consume the medicinal plants grown there.

Table 3: Heavy metal concentration in medicinal plants

\begin{tabular}{|l|l|l|l|l|}
\hline Location & Medicinal plants & $\mathrm{Zn}$ & $\mathrm{Pb}$ & $\mathrm{Cd}$ \\
\hline Industrial area & Carica papaya & $9.36^{\mathrm{e}} \pm 0.95$ & $2.56^{\mathrm{bc}} \pm 0.21$ & $0.008^{\mathrm{d}} \pm 0.001$ \\
\hline & Azadiractha indica & $27.09^{\mathrm{a}} \pm 1.44$ & $2.77^{\mathrm{b}} \pm 0.21$ & $2.000^{\mathrm{a}} \pm 0.156$ \\
\hline & Vernonia amygdalina & $11.43^{\mathrm{d}} \pm 0.87$ & $0.76^{\mathrm{d}} \pm 0.21$ & $0.055^{\mathrm{d}} \pm 0.021$ \\
\hline & Citrus sinensis & $7.97^{\mathrm{g}} \pm 1.33$ & $2.40^{\mathrm{c}} \pm 0.28$ & $0.002^{\mathrm{d}} \pm 0.001$ \\
\hline & Psidium guajava & $19.77^{\mathrm{b}} \pm 1.17$ & $2.28^{\mathrm{cd}} \pm 0.51$ & $1.720^{\mathrm{b}} \pm 0.170$ \\
\hline & Ocimum gratissimum & $5.06^{\mathrm{gh}} \pm 0.35$ & $2.55^{\mathrm{bc}} \pm 0.35$ & $0.005^{\mathrm{d}} \pm 0.002$ \\
\hline & Mangifera indica & $15.45^{\mathrm{c}} \pm 0.92$ & $4.58^{\mathrm{a}} \pm 0.51$ & $1.190^{\mathrm{c}} \pm 0.099$ \\
\hline Residential area & Carica papaya & $4.05^{\mathrm{h}} \pm 0.21$ & $0.40^{\mathrm{de}} \pm 0.14$ & $0.004^{\mathrm{d}} \pm 0.001$ \\
\hline & Azadiractha indica & $9.00^{\mathrm{ef}} \pm 0.57$ & $0.25^{\mathrm{e}} \pm 0.07$ & $0.008^{\mathrm{d}} \pm 0.001$ \\
\hline & Vernonia amygdalina & $1.66^{\mathrm{j}} \pm 0.54$ & $0.15^{\mathrm{f}} \pm 0.07$ & $0.002^{\mathrm{d}} \pm 0.001$ \\
\hline & Citrus sinensis & $3.21^{\mathrm{i}} \pm 0.57$ & $0.75^{\mathrm{d}} \pm 0.21$ & $0.003^{\mathrm{d}} \pm 0.001$ \\
\hline & Psidium guajava & $6.40^{\mathrm{gh}} \pm 0.42$ & $1.10^{\mathrm{d}} \pm 0.28$ & $0.002^{\mathrm{d}} \pm 0.001$ \\
\hline & Ocimum gratissimum & $1.15^{\mathrm{j}} \pm 0.09$ & $0.27^{\mathrm{e}} \pm 0.06$ & $0.001^{\mathrm{d}} \pm 0.000$ \\
\hline & Mangifera indica & $8.07^{\mathrm{f}} \pm 0.06$ & $0.86^{\mathrm{d}} \pm 0.06$ & $0.005^{\mathrm{d}} \pm 0.002$ \\
\hline
\end{tabular}

$a, b, c, d, e, f, g, h, i, j$, means in a column with different superscript are significantly different $(P<0.05)$. Values are mean \pm standard deviation of 3 replications

The concentration of $\mathrm{Pb}$ increased from $0.15 \pm 0.07 \mathrm{mg} / \mathrm{kg}$ (Vernonia amygdalina) at the residential area to $4.58 \pm 0.51 \mathrm{mg} / \mathrm{kg}$ at the industrial area (Mangifera indica). The level of $\mathrm{Pb}$ in this study is higher than $0.25 \pm 0.00088$ to $2.34 \pm 0.0173 \mathrm{ppm}$ (Kulhari et al., 2013) but well below 1.1 to 195.9 $\mathrm{mg} / \mathrm{kg}$ in Urtica dioica, Hypericum perforatum, Achillea millefolium, and Plantago lanceolata around a smelter at Slovenia (Glavac et al., 2017), 1.0 to $23.52 \mathrm{mg} / \mathrm{kg}$ in Petroselinum crispum, Ocimum basilicum, Salvia officinalis, Origanum vulgare, Mentha spicata, Thymus vulgaris, and Matricaria chamomilla in the United Arab Emirates, UAE (Dghaim et al., 2015), 19.50 to $121.3 \mathrm{mg} / \mathrm{kg}$ in Plantago lanceolata at polluted areas of Poland (Nadgorska-Socha et al., 2013), and $102.3 \mathrm{mg} / \mathrm{kg}$ in Urtica dioica at polluted areas of Macedonia (Gjorgieva et al., 2010). The level of $\mathrm{Pb}$ in our study is below the permissible limit (PL) $10 \mathrm{mg} / \mathrm{kg}$ set by Codex Alimentarius Commission, FAO/WHO (2006) for medicinal plants and herbs. Notwithstanding this, the use of these medicinal plants on a regular basis can increase the accumulation of $\mathrm{Pb}$ in human's body beyond the permitted limit, and this could pose serious health issues for them. Accumulation and magnification of heavy metals in human tissues through consumption of herbal remedies can cause hazardous impacts on health (Kulhari et al., 2013).

Cadmium concentration in this study range from $0.001 \pm 0.00 \mathrm{mg} / \mathrm{kg}$ (Ocimum gratissimum) at the residential area to $2.00 \pm 1.56 \mathrm{mg} / \mathrm{kg}$ at the industrial area (Azadiractha indica). The level of $\mathrm{Cd}$ in this study is well below 0.20 to $16 \mathrm{mg} / \mathrm{kg}$ in Urtica dioica, Hypericum perforatum, Achillea millefolium, and Plantago lanceolata around a smelter at Slovenia (Glavac et al., 2017), 5.70 to 13.8 $\mathrm{mg} / \mathrm{kg}$ in Plantago lanceolata at polluted areas of Poland (Nadgorska-Socha et al., 2013) and 7.37 $\mathrm{mg} / \mathrm{kg}$ in Urtica dioica at polluted areas of Macedonia (Gjorgieva et al., 2010) but higher than 0.1 to $1.11 \mathrm{mg} / \mathrm{kg}$ for Cd in Petroselinum crispum, Ocimum basilicum, Salvia officinalis, Origanum vulgare, Mentha spicata, Thymus vulgaris, and Matricaria chamomilla in the United Arab Emirates, UAE (Dghaim et al., 2015). The level of Cd in our study is well above the permissible limit (PL) $0.3 \mathrm{mg} / \mathrm{kg}$ set by FAO/WHO (2006) for medicinal plants and herbs. The level of $\mathrm{Cd}$ in the samples of medicinal plants is 6.67 times higher than the permissible limit (PL) $0.3 \mathrm{mg} / \mathrm{kg}$ set by Codex Alimentarius Commission, FAO/WHO (2006) for medicinal plants and herbs. The safety and benefits of medicinal plants are directly connected to its composition and or quality.

Consequently, the use of medicinal plants grown at the industrial area of Enyimba city can be a major route of entry of $\mathrm{Cd}$ in human body at the study area, which can be very deleterious to health. Kidney is the critical target organ in the exposed population and excretion of $\mathrm{Cd}$ is very slow and it 
accumulates in human kidney for a relatively long time, resulting in an irreversible impairment of the renal tract (Martin and Griswold, 2009; Li et al., 2012; Maobe et al., 2012; Dghaim et al., 2015). Generally, the concentrations of heavy metals in medicinal plants followed an increasing order: $\mathrm{Cd}<$ $\mathrm{Pb}<\mathrm{Zn}$.

\subsection{Conclusion}

The study shows that industrial activities are one of the anthropogenic sources of metals in the environment. Comparison with an international (Dutch criteria and FAO/WHO Codex Alimentarius Commission) standard i.e. the international scientific literature, shows that the level of metal contamination in soil and accumulation in plant is high. The Azadiractha indica clearly has an inherent potential to take up metals from the soil compared with the other plants tested and could constitute serious health risk when used by consumers.

\section{Acknowledgements}

The authors appreciate the Technologists in the Soil Laboratory of National Root Crops Research Institute (NRCRI) Umudike, Abia State, Nigeria for the analysis of the samples tested in this study.

\section{References}

Allen, S.E., Terman, G.L. \& Clements. L.B., (1976). Greenhouse techniques for soil-plant-fertilizer research. Muscle Shoals, National Fertilizer Development Centre.

Bilos, C., et al. (2001). Source, distribution and variability of airborne trace metals in La Plata City area, Argentina. Environmental Pollution, 111: 149-58.

Birch, G.F. and Snowdon A., (2004). The nature and distribution of copper, lead, and zinc in soils of a highly urbanized sub-catchment (iron Cove) of Port Jackson, Sydney. Australian Journal of Soil Research, 42(3), pp. 329-338.

Codex Alimentarius Commission, FAO/WHO, (2001). Food additives and contaminants. Joint FAO/WHO Food Standards Programme, ALINORM 01/12A: 1-289.

Davila, A.F., et al. (2006). Mapping the sources of urban dust in a coastal environment by measuring magnetic parameters of Plantanus hispanic leaves. Environmental Science and Technology, 40(12), pp. 3922-3928.

Dghaim, R., et al. (2015). Determination of Heavy Metals Concentration in Traditional Herbs Commonly Consumed in the United Arab Emirates. Journal of Environment and Public Health, 7:1-6.

El-Desoky, M.A and Ghallab, A., (2000). Pollution impact on soils and plants in an industrial area near Assiut city. Assiut University Bulletin of Environmental Research, 3(1), pp. 1-19.

Fallahzade, J., et al. (2013). Assessment of Heavy Metal Pollution in Soils and Crops of Industrial Sites, Isfahan, Iran. Pakistan Journal of Biological Science, 16(2), pp. 97-100.

Gjorgieva, D., et al. (2010). Content of toxic and essential metals in medicinal herbs growing in polluted and unpolluted areas of Macedonia. Arh Hig Rada Toksikol, 61(3), pp. 297-303.

Glavač, N.K., et al. (2017). Accumulation of heavy metals from soil in medicinal plants. Arh Hig Rada Toksikol, 68(3), pp. 236-244.

Hina, B., (2011). Determination of toxic metals in some herbal drugs through atomic absorption spectroscopy. Pakistan Journal of Pharmaceutical Science, 24(3), pp. 353-358.

Imperatoa, M., Adamo, P., Naimo, D., Arienzo, M., Stanzione, D. et al. (2003). Spatial distribution of heavy metals in urban soils of Naples city (Italy). Environmental Pollution, 124:247-256. 
Keay, R.W.J. (1959). An outlines of Nigeria vegetation. 3rd ed. Government Printer, Lagos, Nigeria.

Kulhari, A., Sheorayan, A., Bajar, S., Sarkar, S., Chaudhury, A. et al. (2013). Investigation of heavy metals in frequently utilized medicinal plants collected from environmentally diverse locations of north western India. SpringerPlus, 2(1), pp. 676-684.

Li, S.M., et al. (2012). Heavy metals in Chinese therapeutic foods and herbs. Journal of Chemical Society Pakistan, 34(5), pp. 1091-1095.

Logan, T.J. and Miller, R.H., (1983). Background levels of heavy metals in Ohio farm soil. Research Circular, 275: 3 - 15.

Maobe, M.A.G., et al. (2012). Profile of heavy metals in selected medicinal plants used for the treatment of diabetes, malaria and pneumonia in Kisii Region southwest Kenya. Global Journal of Pharmacology, 6(3), pp. 245-251.

Martin, S. \& Griswold, W. (2009). Human health effects of heavy metals, in Environmental Science and Technology Briefs for Citizens, 15:1-6, Center for Hazardous Substance Research, Manhattan, Kan, USA.

McGrath, S.P., et al. (2001). Plant and rhizosphere process involved in phytoremediation of metalcontaminated soils. Plant Soil, 232(1-2), pp. 207-214.

Ministry of Agriculture, Fisheries and Food, MAFF., 1981. Code of good agriculture practice for the protection of soil. Draft consultation document. London Academic S.L. Leon., 221: 45

Moreno, J.L., et al. (2003). Toxic effect of cadmium and nickel on soil enzymes and the influence of adding sewage sludge. Eurasian Journal of Soil Science, 54(2), pp. 377-386.

Nadgórska-Socha, A., et al. (2013). Heavy metal bioaccumulation and antioxidative responses in Cardaminopsis arenosa and Plantago lanceolata leaves from metalliferous and non-metalliferous sites: a field study. Ecotoxicology, 22(9), pp. 1422-34.

NESREA., 2011. “1st Eleven Gazetted Regulations Federal Republic of Nigeria Official Gazette”.

Ogundele, D.T., et al. (2015). Heavy Metal Concentrations in Plants and Soil along Heavy Traffic Roads in North Central Nigeria. Journal of Environmental Analysis and Toxicology, 5(6), pp. 334338.

Ożarowski, A. \& Jaroniewski W., (1987). Medicinal plants and their medical use. Publishing Institute Trade Unions Warsaw.

Reeves, R.D. \& Baker, A.J.M., (2000). Metal accumulating plants. In: Raskin, I. and Ensley, B.O. (eds), phytoremediation of toxic metals: Using plants to clean up the environment. John Wiley and Son Inc., New York, USA.

Türkdogan, M.K., et al. (2003). Heavy metals in soil, vegetables and fruits in the endemic upper gastrointestinal cancer region of Turkey. Environmental Toxicology and Pharmacology, 13(3), pp. 175-179.

Wikipedia 2013. Dutch Standards for heavy metals in soil [Internet], Available from: www.en.wikipedia.org/wiki/Dutch_standards. [accessed 28 May 2013].

World Health Organization, WHO (2002). Managing water in the home: Accelerated health gains from improved water supply, Geneva.

World Health Organization, WHO Guidelines for Assessing Quality of Herbal Medicines with Reference to Contaminants and Residues, World Health Organization, Geneva, Switzerland, 2006. 